\title{
Re-running Eligibility on Fiscal Spending Behavior: Evidence from Indonesian Municipalities
}

\author{
Setyo Hari Priyono ${ }^{1}$ \\ Ministry of National Development Planning/Bappenas - Indonesia \\ Prani Sastiono ${ }^{2}$ \\ University of Indonesia - Indonesia
}

\begin{abstract}
This study focuses on the difference in spending policy behaviour between regions having re-running incumbents in the 2015 election and regions that have the last-period incumbent. Hypothetically, re-runner incumbents would try to enhance their re-election probability by increasing their targeted expenditures in the times leading to the election time; in contrary, the lastperiod incumbents will do the opposite. Ordinary Least Square (OLS) crosssectional data has been used to analyse the politicians' behaviour on fiscal spending policy for 237 municipalities. The study result shows that there is no difference behaviour between regions having re-running incumbent and regions that have last-period incumbent. Compared to regions with lame ducks, grant expenditure tend to be higher on election year in regions having rerunning incumbent. There is also a tendency that the higher grant expenditure in the year prior to election, the lower grant expenditure during election year in those regions.
\end{abstract}

Keywords: Re-running Eligibility; Fiscal Spending; Municipalities; Regional Election.

\footnotetext{
${ }^{1}$ Setyo Hari Priyono is a Planner Staff at Ministry of National Development Planning Bappenas and a Postgraduate Student Linkage Program at Postgraduate Program in Economics, UI and Economic of Development at International Institute of Social Studies -Erasmus University of Rotterdam, The Hague. Email address: setyo.hp@bappenas.go.id

${ }^{2}$ Prani Sastiono is a lecturer at the Postgraduate Program in Economics, Faculty of Economics and Business, University of Indonesia.
} 


\title{
Re-running Eligibility on Fiscal Spending Behavior: Evidence from Indonesian Municipalities
}

\author{
Setyo Hari Priyono and Prani Sastiono
}

\section{Introduction}

Prior studies on the executive officers show that re-election eligibility can lead politicians to increase their re-election probability. The rational include, such as exceeding budget spending, budget deficit policy, maintaining tax in the lower level or managing budget composition during election time to attract voters' preference (Klein, 2010; Drazen and Eslava, 2010; Klein and Sakurai, 2015). However, most existing literature focus on election time and only a few studies are cognisant of and emphasize on the eligibility of being re-elected. Eligibility for being re-elected is key, since not all incumbents are eligible, nor have the desire to be re-elected. The eligible incumbents who seek for re-election tend to build their reputation, and manage some specific budget composition that has strong preferences to please prospective voters such as investment expenditures (construction of roads, hospitals, etc) over the less-visible like current expenditures (wages and payments) (Vergne, 2009; Drazen and Eslava, 2010; and Klein and Sakurai, 2015). In contrast, those who are ineligible to re-run the election may not apply an opportunistic fiscal policy, since they have no political motive, nor have less incentive to do so (Klein and Filho, 2011; Klein and Sakurai, 2015; Fonseca, 2015).

In the most developing countries, electorates have difficulties to monitor the incumbent's competency level due to asymmetric information. The chance to be re-elected by incumbents and imperfect information by electorates on the other side will render more motivation to re-runner politicians to act more aggressively pertaining to spending policy, and in turn leads to moral hazard. They will maximise their resources in their first period taking account the election time, in view of improving their vote-share later on (Shi and Svensson, 2003; Besley and Case, 1995; Drazen, 2008; Escaleras and Calcagno, 2009; Sakurai and Klein, 2015)

Existing literatures have indefinite conclusions whether re-election eligibility has an effect on budget implementation or not. Many of them show that it has a positive and significant effect on fiscal spending behaviour, meanwhile, other studies have shown the opposite result. Previous studies by Johnson and Crain (2004); Besley and Case (1995, 2003); Escaleras and Calcagno (2009) Benitto et al. (2012); and Klein and Sakurai (2015) showthat re-running incumbent spend more in total and allocate more on highly visible and targeted 
expenditure upon voters towards the election. However, studies by Nogare and Ricciuti (2011) and Fonseca (2016) in Italy and Portugal respectively find that rerunning eligibility has insignificant relationship on per capita spending, while in Portugal ineligible incumbents act more conservative that keep maintaining collecting more tax in opposite with their people opportunistic behaviour regarding fiscal policyAfter "Reformasi" in 1998, Indonesia has undergone democratisation processed and transferred a significant degree of power to its local governments, particularly in the district level. However, misuse of local budget, money politics, patronages, and political dynasties are still widespread in terms of local politics throught the country. Many scholars suggest that the regional elections were still stained by rent-seeking behaviour, transactional politics, throughout the parties' internal selection process of candidates to the voting period (Aspinall, 2014; and Henderson and Kuncoro, 2011). The existence of regional head officer's tenure limitation law, which stipulates that a candidate can be elected for two consecutive times, may persuade incumbents to act more aggressively to attract prospective voters.

Since regional autonomy is heavily concentrated in municipal level, it is important to analyse the behavior of Indonesian local head executives at subnational level. The local executive heads have been given many authorities including on fiscal policy, while there are some budget components that are at their discretion judgment. These budget namely "discretionary funds" could be intentionally utilized to impress the voters and enhance their re-election prospect later on (Sjahrir et al., 2013; Winoto and Falikhatun, 2015). Re-running candidates also tend to allocate the budget not based on reliable benchmarks but depend on their vested interests (Ritonga and Alam, 2010). These kind of spending categories usually budgeted as grants, social aid, and financial assistance to lower government levels (sub-districts and villages), along with investment expenditures are expected to attract electorates (Sjahrir et al., 2013, Arifin and Purnomowati, 2017, Setiawan and Rizkiah, 2017).

This research will focus on the regional public expenditure policy that indicated as having relationship with the political events. Local government, however, remained reliant on the central government as evidenced by substantial intergovernmental transfer funds. Brodjonegoro (2001) and Blondal (2009) also argue that the fiscal decentralization process in Indonesia focuses on expenditure decentralization which approximately account for 90 percent of their total budget.

The Indonesian government has revised the regulation to minimize misuse of local budget by the regional government. Ministry of Home Affairs (MOHA) has stipulated Regulation No.39/2012 mandating that the distribution of grant and social assistance should mention specifically the target of beneficiaries. Previous studies show that misuse of budget spending is closely related to election time and stronger in incumbent regions (Sjahrir, et al., 2013; 
Arifin and Purnomowati, 2017). However, the implementation of Regulation No. $39 / 2012$ on grants and social assistance distribution remains under studied. The election year is also well-known as the peak time and the re-running incumbents allegedly use budget spending optimally to increase their popularity (Besley and Casey, 1995, 2003; Sjahrir et al., 2013; Klein and Sakurai, 2015).

This study will examine the difference spending policy behaviour in the region having incumbents who are eligible to re-run the election and in the regions whose executive heads already serve for two periods. In this study, the different behavior is examined through increased government expenditures, by analysing total expenditure, investment expenditure, and discretionary funds as an aggregate, and disaggregating its subcategories namely: grants, social aids, financial assistance expenditure regarding the election year. This study focuses on 237 municipalities in Indonesia which held simultaneous direct local elections in 2015, not inclusive of 9 municipalities that have eligible incumbent but did not see a re-run, 9 provincial regions, and 14 newly-formed regions invloving in the local concurrent election.

According to the results, in general, there is no different behavior between regions that have re-running incumbent and regions that have lastperiod incumbent during election year except in the grant subcomponent. Regions that have re-running incumbents are more likely to increase in the grant spending subcomponent in the election time compared to regions that have last-term period incumbents. However, the higher grant expenditure in a year before the election time, then the lower grant expenditure during election year in those regions.

The paper is organized as follows. Chapter 1 on Introduction discusses the importance of re-running eligibility on budget spending behaviours and some brief fundamental arguments. Chapter 2 contains Literature Review and Empirical Evidence that discuss theories of re-running eligibility and its link with the implementation of local fiscal policy expenditure. Chapter 3 on Data and Methodology details variables used in the study including sources of the data, and the model used to answer research questions. Chapter 4 presents the main empirical results and how they relate to the theoretical background exposed in the earlier chapter. Chapter 5 On conclusion summarizes the findings and provides recommendations for future work.

\section{Literature Review}

The incumbent's incentive to manage fiscal policy prior to elections has been extensively analyzed by both economics and political science scholars alike, and supported by diversified theories. One of the main purposes of incumbent to do such policy is the probability of being re-elected. Nordhaus (1975) initially introduced a theory of politically induced cycles by proposing a model whereby incumbents would utilize the macroeconomic policy (balance 
deficits policy, unemployment policy, and inflation policy) in order to gain electoral advantages. The model assumes that the incumbents would attempt to create the most wanted economic conditions before elections by applying expansionary fiscal policies to stimulate economy growth and create constructive circumstances (Nordhaus, 1975).

Another concept is introduced by Rogoff and Sibart (1988), and Rogoff (1990) when narrowing the scope of discussion from macroeconomic perspective to only fiscal policy. Both scholars mention that incumbents who seek to re-run the election try to send signal of competency upon the electorates by using government spending to increase fiscal policy performance prior to election time. However, the electorates face asymmetric information and struggle to measure politicians' performance correctly. This circumstance is often followed by moral hazard, and leads politicians who are eligible to re-run the election to more opportunistic behavior to gain their vested interest (Shi and Svensson, 2006).

Moreover, the larger number of electorates usually in lack of capability to identify election-induced fiscal policy manipulations and the incumbent's competence, the more incumbents may get benefit from boosting targeted expenditures that has close relationship regarding election outcomes. The targeted expenditures in order to please electorates comes from several categories such as investment expenditures (building roads, bridges, etc), subsidies, donations, and so forth that are higher in an election period than in a non-election period. As a result, swing voters will likely keep voting for incumbents who provide more targeted expenditures despite the public understanding that such expenditures may have electoral motivation afterwards (Shi and Svensson, 2006).

A study by Baleiras and Santos (2000) using their 'rational-expectations opportunistic-type' model, suggest that when the re-run opportunity emerges and there is a motivation for re-election, in-office politicians tend to maximize budget spending during their office time periods, which reaches a peak in particular in the pre-election time (Balerias and Santos, 2000). Other studies also mention that the possibility to re-run in election induce incumbents' incentives to send signal as a 'higher competent' agents and in line with their populist policy campaign upon their prospective supporters (Baleiras and Santos, 2000; Johnson and Crain, 2004; and Smart and Sturm, 2013). However, the experienced office-holders who have no concerns on re-election matter will have no longer motives to give a good signal, since they do not gain benefits afterwards. Those who are not allowed nor have desire to re-run the election because of specific motives (e.g. running for gubernatorial or legislative election, facing criminal investigation, returning to the initial post, retired) may not apply such an opportunistic fiscal policy as much as re-runner incumbents (Sjahrir et al., 2013; Besley and Casey, 1995; Fonseca, 2016). 
However, the works of Besley and Casey (1995) and Drazen and Eslava (2010) also notice another unique behavior possibility where lame ducks may exhibit the opportunistic behavior at their end of office period. Allegedly, they have two scenarios towards their post-office life: 1) Lame ducks also attempt to build reputation to their special further purposes, like running gubernatorial or legislature election, improve the preferred candidate re-election chances; or 2) They become more truthful, caring less about their reputation and keep continuing their usual business plan. It means, the last-period incumbents tend to choose the pave with the least risk for their future career by applying truthful policy, leaving the office with a good legacy, and with a hope of having similar image as eligible incumbents.

Existing literatures of re-running possibility on fiscal policy outcome have raised mix results, whether it has effect on budget implementation or not. Researching on fiscal outcome and the effect of incumbent period limits the studies of Besley and Case $(1995,2003)$ and Alt et al. (2011) in the states that only possible to rerun in election two consecutive time maintain that incumbents try to build their image upon voters when there is a possibility to re-run election. The result of the studies shows that in the states where first-term governors, income growth tends to be higher since they care about maintaining political good image upon their prospective electorate.

Other observation by Johnson and Crain (2004) updating Besley and Case's $(1995,2003)$ earlier studies, and Nogare and Ricciuti (2011) to a panel of 48 and 52 democraties nation respectively. Both studies have opposite results. The first study, using cross-national data, finds that in-tenure restrictions affect fiscal outcome differently depending on the implementation of a one-term and two-term rule in the observed countries. In contrast, Nogare and Ricciuti (2011) find that in countries with presidential system, those who are eligible for reelection seems to enhance their spending, while in other governmental systems there is no significant effect on either fiscal spending policy as well as budget balance.

Studies by Padovano and Petrarca (2014), Klein and Sakurai (2015), and Lopes da Fonseca (2016) on Italian, Brazilian, and Portugal municipalities respectively show that the re-eligible in-office candidates seems likely to focus on maintaining tax setting in lower level during election year compared to the other years within their period. Eligible re-runners in Brazil and Portugal municipalities eligible however act oppositely while in terms of current expenditure policy. In Brazil, they tend to reduce less favorably for electorates expenditure such as current expenditure and exceed spending in capital expenditures and total expenditures (Klein and Sakurai, 2015). Their evidence shows that re-runners focus on certain highly concerned spending by electorates including capital investment expenditure, while reducing the total 
spending to send a good message that they have higher-level competences. In contrast, in Portugal, they tend to increase in current expenditure during election time where subsidies and personnel budget are included in this category. Their explanation is that the incumbents eligible for re-election have appeared to engage in distortionary policies relative to the last-period incumbents (Fonseca, 2016).

Specific to the local governments in Indonesia, Ritonga and Alam (2010) find that the allocation of grant and social assistance expenditure in incumbent regions during the election year is higher than prior to the elections. As mentioned, evidence from the studies by Sjahrir et al. (2013) and Winoto and Falikhatun (2015) find that discretionary funds spending is positive and significant nearing and during election time respectively. Taufiq and Purnomowati (2017) investigate the possibility of misuse of discretionary funds in local governments' budget by incumbents before election and find higher proportion of budget allocation on grant and social assistance expenditure related to incumbent regions during the local election in 2015.

Law No. 8 of 2015 mandates that from 2015 to 2018, local elections have to be implemented every 5 (five) years simultaneously on the same date throughout the territory of the Republic of Indonesia (Republic of Indonesia, 2015). The election on 9 December 2015 was only one of the three rounds of simultaneous regional elections in Indonesia covering 269 regions in Indonesia; other rounds were held in 2017 and 2018. According to the regional law, the regional executives are elected as a pair. However, the person who can rule the region as well as has discretionary power attached to the regional head instead of his vice. Furthermore, the vice regional head only supports and give advice to the elected mayors. Therefore, this study will be limited incumbent that has an eligibility to re-run in the election in two circumstances. First, when the regional head and his vice split and re-run as competitor, then the regional head become an eligible incumbent instead of his deputy since he has discretion control. Second, when only the vice regional head able to re-run in the election while the regional head decide to not re-run the election because of any specific reason (running governor election, retired, etc) or ineligible to re-run the election due to the limit of tenure, then he cannot also be called as an eligible incumbent candidate.

\section{Methodology}

This research uses a set of data on public spending of districts and municipalities which held simultaneous direct head local elections over the period 2013-2015. The unit of observation is the municipality level in Indonesia held regional election in 2015, a total of 237 districts and cities. Data related to local government expenditures are resourced from the reports by Directorate General of Fiscal Balance, Ministry of Finance and Government Financial 
Statistics Regency/City from Statistics Indonesia (Central Statistics Agency/ BPS). Political data consisting of the incumbents eligible for running re-election and decide to re-run in the election, and the last-period incumbents also local election result, were obtained from various sources, including General Election Commission (KPU), Ministry of Home Affairs (KPU, MoHA), and The Association for Elections and Democracy (Perludem).

This study also uses several control variables to describe districts' socialeconomics and demographic. The demographic data used to describe society condition in regions, represented by adult literacy rate and population between 2013 and 2015 is extracted from the National Socio-economy Survey (Susenas), and 2010 Indonesia Population Census and its projection, respectively. Other control variables are district size and dummy cluster Island as released from MoHA and Ministry of Economic Affairs (MoEA), respectively.

In this research, a model is used to analyze the difference in the behavior on fiscal performance between eligible re-runner and those in the last term. The model also analyses the current office holder behavior by capturing the amount of local government expenditure persistence in a two-year prior to the election time frame. The model is specified as follows:

$$
y_{i 2015}=\alpha+\gamma_{1} y_{i 2014}+\gamma_{2} y_{i 2013}+\beta_{1} \operatorname{Rerun}_{i}+\beta_{2} y_{i 2014} * \operatorname{Rerun}_{i}+\delta X_{i k}+u_{i}
$$

This study estimates the equation using the fiscal policy variables $y_{i 2015}$ on the left-hand side, which include total expenditures and budget deficits. This study also examines the highly visible to the electorate expenditures $y_{i 2015}$ namely investment expenditure and discretionary expenditures (consist of grants, financial assistance, and social assistance expenditure). All dependent variables are expressed in logarithmic terms. The vector $X_{k i t}$ are control variables representing economic, demographic, and political variables that affect local budget performance. The main variable of this study is Rerun, a dummy variable to capture an eligibility of current incumbents for re-running re-election and the decision to re-run. This study also analyses the interaction between the eligible incumbent and seek for re-election and the lag of the dependent t-1 $y_{i 2014} *$ Rerun $_{i}$, variable used to capture persistence in the fiscal variables.

Other factors include Revenue (InRevenue); education rate of the people proxy by adult literacy rate (LitRate); total population size (InPopsize); DisctrictSize by constructing a variable in logarithms as well. Regarding literacy rate, this study excludes a demographic variable that represents the percentage of the population under 15 years old (\% Pop < 15), ineligible to vote in any elections. A dummy City and Islandscluster variable are in place to capture the heterogeneity as well as financial disparities of each regions. Finally, the variable denotes $u$ represents the regression error term. 
This empirical model uses cross-sectional data and we apply typical Ordinary Least Square (OLS) estimators. However, in order to minimize heterogeneity problem robust option is added by through applying several steps. First step is analyzing the re-runner in the election incumbents on fiscal spending behavior with full observation (246 municipalities) including 9 municipalities that have the eligible incumbents that have no desire to be reelected. Then, this study also examines the opportunistic behavior of the eligible incumbents'. The last step, this study analyses the behavior through dropping the municipalities that no allocating any budget in grants, social assistance, and financial assistance expenditure. These steps are important to know whether the result have similar pattern or not.

The coefficient $\beta_{1}>0$, will confirm the basis argument of re-runner incumbent opportunistic behaviour proposition (Besley and Case, 1993, 2005; Sjahrir et al., 2013; and Klein and Sakurai, 2015). It suggests that incumbents who are not re-running in the election for the second tenure act differently than those who seek for another term, which is more truthful, conservative, and have less incentive to manipulate local budget.

According to the underline argument on the theoretical framework, in this study, the persistence of budget spending behavior by re-runner incumbents can be assessed through an increase in government spending by reviewing total expenditures, investment expenditures, and discretionary expenditures in sum and its each subcategory including grants, social assistance, and financial assistance expenditure in the year before and during the election year.

The first dependent variable is total expenditure. Re-runner can increase the total expenditures to finance their populist programs to persuade prospective voters. They try to build their image while keep controlling budget deficit to reflect that they are capable leaders to enhance re-election prospects (Veiga and Veiga, 2007; Drazen and Eslava 2010; and Chortareas, 2016). Regarding investment expenditure, re-runner incumbents tend to spend more in this type of expenditure that is favored by voters and potentially have large benefit due to the election prospects. Several studies find evidences which suggest that election-year interaction with incumbents and public spending become relatively more visible, as reflected in healthcare, educational, and infrastructure construction spending approaching election years, than less visible expenditure such as current expenditures, in particular wages and subsidies (Veiga and Veiga, 2007; Drazen and Eslava 2010; and Chortareas, 2016). This particular fiscal spending categories has highly visibility to attract prospective supporters and to gain higher vote-share likelihood. Therefore, an eligible incumbent candidate is expected to have a positive relation to investment expenditure. 
The last discussion is related to Discretionary funds and its disaggregation: grant, social assistance, and financial assistance expenditure. These expenditure categories can be spent relatively flexible in contrast to other type of expenditures and have displayed a strongly cyclical behavior in direct elections, especially when the incumbent is re-running the election (Sjahrir et al., 2013). Other studies on incumbent regions such as Ritonga and Alam (2010) and Winoto and Falikhatun (2015) investigate the allocation of donation and social assistance expenditures between incumbent and non-incumbent candidates and find that the distribution of donation and social assistance expenditure in incumbent regions during the election year was higher compared to approaching the election time. In this study, an eligible incumbent candidate is expected to have a positive relation to discretionary funds as aggregate, and when differentiate it to grants, social aids, and financial aids expenditure. Therefore, this study hypothesis is:

H1: Regions that have eligible incumbents who decide to re-run the 2015 election will have higher fiscal spending compared to regions with last-term incumbents $\left(\beta_{1>0}\right)$.

\section{Result and Analysis}

Descriptive analysis provides an overview of the basic features of the data that used in the research. This analysis also describes the modest synopses related to the observation (population or sample) as well as its measures. The descriptive statistics of this study is presented in Table 1 below.

Table 1. Descriptive Statistics (1)

\begin{tabular}{l|l|l|l|l|l}
\hline Variable & Obs & Mean & Std. Dev. & Min & Max \\
\hline Rerun & 237 & 0.65 & 0.48 & 0 & 1 \\
Literacy Rate & 237 & 94.59 & 8.18 & 32.56 & 100 \\
Popsize & 237 & $485,827.8$ & $544,445.1$ & 18,186 & $3,534,114$ \\
District Size & 237 & $6,829.093$ & $25,929.1$ & 25.24 & 313,040 \\
Island Cluster & 237 & 2.01 & 1.725877 & 0 & 5 \\
Revenue & 237 & $1,345,470$ & $838,656.8$ & $223,282.9$ & $6,619,031$ \\
\hline
\end{tabular}

Source: Dataset constructed by the author

The table shows a summary of all variables that used in this study. Total observations are 237 regions (districts, and cities) which held a simultaneous direct head election in 2015, not inclusive 9 municipalities that have eligible incumbents but not re-run in the election. First, statistical description above shows that the mean value of re-runner is 0.66 , which means the region held a simultaneous direct election that has re-running incumbent is 64 percent or around 153 regions. Second, the mean of adult literacy rate in Indonesian regions held the occurrence election in 2015 is 94.59 percent which is sufficiently high. 
In the district size, in average observed municipalities have an area about 6664.99 per square kilometre, with standard deviation of $25464.97 \mathrm{~km}$. Finally, in dummy variable island clusters show the mean of island clusters is 2.01, with a standard deviation of 1.72 consisting six main island development corridors with Java Island as base. In terms of Revenue, the mean value of is $1,345,470$ (in million rupiah) and the standard deviation is 838,656 (in million rupiah). However, the minimum value is 223,282 (in million rupiah) in Bantul, and the maximum value is 619,031 (in million rupiah) for Teluk Bintuni. The descriptive statistics of fiscal variable in this study is presented in Table 2.

Table 2. Descriptive Statistics (2)

\begin{tabular}{l|r|c|r|r|c}
\hline \hline \multicolumn{1}{c|}{ Variable } & Obs & Mean & Std. Dev. & Min & Max \\
\hline \hline Total Expenditure & 237 & $1,381,494$ & $906,258.1$ & $477,740.6$ & $6,775,373$ \\
Investment Exp. & 237 & $335,319.5$ & $303,463.8$ & $51,980.73$ & $2,820,502$ \\
Discretionary Funds & 237 & $148,423.7$ & $113,667.4$ & $1,487.206$ & $626,159.4$ \\
Grant Exp. & 237 & $60,942.23$ & $50,660.72$ & 0 & $292,942.6$ \\
Social Assistance Exp. & 237 & $7,924.658$ & $13,352.58$ & 0 & $102,557.5$ \\
Financial Asisstance Exp. & 237 & $79,556.81$ & $81,523.04$ & 0 & $502,359.8$ \\
\hline \hline
\end{tabular}

Source: DJPK, Dataset constructed by the author Note: in million rupiahs

On total expenditures, the mean value is $1,381,494$ (in million rupiah) with standard deviation of 906,258 . The minimum value is 477,740 (in million rupiah), which for Kota Solok, and the maximum value is 6,775,373 (in million rupiah), which in Kutai Kartanegara. It means that Kota Solok spent 477 million rupiah in 2015, while Kutai Kartanegara spent around 6.8 trillion rupiah in 2015, being the highest.

On the investment, expenditure has a mean value of 335,319 and the standard deviation is 303,463 . The maximum value of investment expenditure is $2,820,502$ (in million rupiah), which for Kutai Kartanegara, and the minimum value was 51,980.7 (in million rupiah), which for Rembang regency. It means that Kutai Kartanegara spent their capital budget for around 2,8 trillion rupiahs, while Rembang expended 51,9 billion rupiahs in capital expenditure category.

The summary of discretionary funds category for regions held a simultaneous direct election in 2015 are as follows. The discretionary funds per se have the mean value of 11.61 , while the standard deviation is 0.83 . It also has the minimum amount of 1,487 (in million rupiah) for Kota Pemalang and has the highest value of 626,159 (in million rupiah) in Bengkalis. It means, Bengkalis district allocated more than 600 billion rupiahs in "flexible" category budget, in opposite way, Kota Pemalang only allocate 1,48 billion rupiah in this sector budget. 
The regression result, showing the effect of the eligibility of being reelected on fiscal outcome in regions conducted simultaneous direct election in Indonesia in 2015, as follow.

Table 3. The Effect of the Eligibility of Being Re-elected on Fiscal Policy

\begin{tabular}{|c|c|c|c|c|c|c|}
\hline \multirow{2}{*}{$\frac{\text { Variables }}{\text { Independent }}$} & \multicolumn{6}{|c|}{ Dependent (InSpending) } \\
\hline & $\begin{array}{l}\text { Total } \\
\text { Exp. }\end{array}$ & $\begin{array}{c}\text { Investment } \\
\text { Exp. }\end{array}$ & $\begin{array}{c}\text { Discretonary } \\
\text { Funds }\end{array}$ & $\begin{array}{l}\text { Grant } \\
\text { Exp. }\end{array}$ & $\begin{array}{c}\text { Social } \\
\text { Aid }\end{array}$ & $\begin{array}{c}\text { Financial } \\
\text { Aid }\end{array}$ \\
\hline \multirow{2}{*}{$\begin{array}{l}\text { Expenditure } \\
(\mathrm{t}-1)\end{array}$} & $0.254^{\star \star}$ & $0.562^{\star \star \star}$ & $0.179 *$ & 0.072 & $0.718^{\star \star \star}$ & 0.076 \\
\hline & $(0.099)$ & $(0.108)$ & $(0.093)$ & $(0.056)$ & $(0.250)$ & $(0.109)$ \\
\hline \multirow{2}{*}{$\begin{array}{l}\text { Expenditure } \\
(\mathrm{t}-2)\end{array}$} & $0.167^{\star \star}$ & 0.083 & 0.099 & $0.263^{\star}$ & $0.212^{*}$ & 0.061 \\
\hline & $(0.073)$ & $(0.080)$ & $(0.072)$ & $(0.159)$ & $(0.112)$ & $(0.063)$ \\
\hline \multirow[t]{2}{*}{ Re-run } & 0.038 & 0.763 & -0.484 & $1.276^{\star \star}$ & -0.478 & -1.545 \\
\hline & $(0.366)$ & $(0.772)$ & $(0.948)$ & $(0.626)$ & $(1.967)$ & (1.271) \\
\hline \multirow{2}{*}{$\begin{array}{l}\text { Re-run*Exp. } \\
(\mathrm{t}-1)\end{array}$} & -0.002 & -0.060 & 0.042 & $-0.150^{\star \star}$ & 0.089 & 0.162 \\
\hline & $(0.027)$ & $(0.062)$ & $(0.086)$ & $(0.067)$ & $(0.218)$ & $(0.137)$ \\
\hline \multirow[t]{2}{*}{ LnRevenue } & $0.580 * * \star$ & $0.485^{\star \star \star}$ & $0.393^{\star *}$ & 0.479 & 0.472 & 0.074 \\
\hline & $(0.111)$ & $(0.103)$ & $(0.191)$ & $(0.320)$ & $(0.558)$ & $(1.065)$ \\
\hline \multirow[t]{2}{*}{ InpPopsize } & -0.013 & $-0.100^{\star *}$ & 0.064 & -0.018 & -0.383 & 0.015 \\
\hline & $(0.018)$ & $(0.043)$ & $(0.080)$ & $(0.135)$ & $(0.296)$ & $(0.445)$ \\
\hline \multirow[t]{2}{*}{ Literacyrate } & -0.000 & $-0.003^{*}$ & -0.001 & 0.012 & 0.004 & -0.023 \\
\hline & $(0.000)$ & $(0.002)$ & $(0.002)$ & $(0.010)$ & $(0.012)$ & $(0.014)$ \\
\hline \multirow[t]{2}{*}{ InDistrictsize } & 0.005 & 0.008 & 0.017 & 0.071 & $-0.262^{*}$ & -0.245 \\
\hline & $(0.006)$ & $(0.020)$ & $(0.047)$ & $(0.126)$ & $(0.143)$ & $(0.355)$ \\
\hline City & Yes & Yes & Yes & Yes & Yes & Yes \\
\hline Islandcluster & Yes & Yes & Yes & Yes & Yes & Yes \\
\hline \multirow[t]{2}{*}{ Constant } & 0.229 & -0.765 & 2.389 & -0.374 & -0.521 & 11.647 \\
\hline & $(0.443)$ & $(0.863)$ & $(1.625)$ & $(2.528)$ & $(5.033)$ & (10.523) \\
\hline $\mathrm{N}$ & 237 & 237 & 237 & 237 & 237 & 237 \\
\hline
\end{tabular}

Source: Author Estimation

Denote significance at the ${ }^{* * *} 1 \% ;{ }^{*} 5 ; *{ }^{*} 10 \%$ levels.

The main interest variable of this study is the interaction of re-running the election factor and targeted budget expenditures category in the election time (Rerun), which identifies the budget utilization deviation between rerunning incumbents and the last-term incumbents in regions conducting 2015 simultaneous election. Moreover, we also analyze persistency of local budget utilization in election year compared to one year and/or second year before the election year. 
The result, shows that in general, there is no difference spending behavior between regions that have re-runner incumbents and regions that have second-period incumbents in most of the observed spending categories during the election year except in the grant subcomponent. Regions that have re-runners are on average have 1.3\% (at 5\% significant level) higher level of grant spending subcomponent compared to regions with last-term incumbents. However, the higher the grant expenditure in a year before the election time (re-run*expenditure $t-1)$, then the lower the grant expenditure during election year in those regions. This regression results show that when regions have incumbent who seek for re-election, on average for every $1 \%$ increase in grant expenditure in the year prior to the election leads to $0.15 \%$ (at $5 \%$ significant level) decrease in grant budget subcategory during election time.

The results in general show that the effect of the re-running eligibility on spending is not statistically significant. This seems to correlate with the fact that among regions with lame duck incumbents, more than half have vice head who were running in 2015 election. This means there might be an incentive for them to use spending to affect their re-electability, which is similar to the condition in regions with re-running head.

However, there is a difference in grant expenditure between regions that have re-running head and regions that have lame ducks. It is likely that rerunner incumbents prefer to choose this kind subcomponent spending that can be utilized for the sake of their group or their vested interest. Grants expenditure become popular among re-running incumbents compared to other type of expenditures, because they can raise the spending in election year to distribute the donation relatively flexible, massive, and seems have direct effect on voter's welfare. They can donate it to religious and/or social institutions (mosques, churches, etc.) civil group activities ("Majlis Taklim", youth organization, NGO at local level) and even sport association to improve their good image upon electorates. In contrast, other type of expenditures, such as investment expenditure in general still needs more time to gain visible results upon voters, while social assistance expenditure usually more focus on individual or families rather than institutions.

This evidence also consistent with previous studies that during the period of the election incumbents tend to increase grant budget spending (Ritonga and Alam, 2010; Arifin and Purnomowati, 2017). Moreover, Ritonga and Alam (2010) works also notice that incumbents tend to allocate more in grant budget subcategory in the election time compared to a previous year of the election time.

The implementation of the Minister of Home Affairs Regulation Number 39 of 2012 which gives stricter rules to allocation of grant, however, still not enough to control an opportunistic behavior in expenditure during the 2015 
regional head general election. Therefore, the existence of the restrictions on grant expenditure and social assistance expenditure based on the regional government regional finance ability (fiscal space) is urgently needed. This prohibition should be stated in the government regulation policies to improve the existing regulation on donation and social aid distribution.

In the 2015 simultaneous regional election, according to KPU (2017) studies there was a phenomenon that in the region that incumbents re-running the election tend to fulfil the election budget that requested from the regional election commission. According to Law No. 10/2016 on Governor, Regents, and Mayor Elections, regional elections are funded by regional government budget and put the budget on the grant subcomponent. As a result, local government has to finance in order to conduct the regional election from their own budget, and allocate it as a grant to the regional election commission (KPK, 2018). They seem likely that they have their vested interest to ensure the election held well and at the same time will increase their good image as a capable leader.

The effect of incumbents' eligibility interaction on fiscal policy in 2015 is also influenced by budget expenditure in the previous year. As mentioned, it is shown that in most of the observed expenditure categories in 2015 has a positive and significant with the budget period of the year before election time (Expenditure t-1), except in grant and financial assistance budget subcategories. Regarding total expenditures and investment expenditure, the result confirms that if there is a change in one year prior to election time by 1 percent, we would expect that such expenditures in 2015 to change by 0.25 per cent and 0.56 per cent (at 5 per cent and 1 per cent significant level respectively). Similarly, a positive and significant relationship also occurs in discretionary funds as an aggregate, and when differentiate into social assistance expenditure. If there is a change by 1 per cent in 2014 budget spending, we expect that such expenditures in election time (2015) to change by 0.18 percent, and 0.72 per cent respectively. However, within two years prior to election budget expenditure (Expenditure $t-2$ ) only in social assistance spending that demonstrates a dependent relationship. It means, if there is a change by 1 percent in social assistance expenditure in two years before election, there will be a change by 0.24 per cent in 2015 (at 5 per cent significant level). These pieces of evidence are aligned with the existing studies, where there is a significant increase in both discretionary funds in a year before election (Arifin and Purnomowati, 2017) and by disaggregating into grant expenditure (Arifin and Purnomowati, 2017; Setiawan and Rizkiah, 2017). Moreover, Arifin and Purnowati (2017) works also suggest that during 2 years prior to election there are might be a misuse of regional budgetary spending and revenue for the sake of individual and groups, in particular in social assistance spending in order to create impression upon the voters. 
The control variables show that regional budget spending has positive and significant relationship with the total income of the region. These ciscumstances that can reflect well-functioning economy circumstance in its regions (Escaleraz and Calcagno, 2009; Sjahrir et.al, 2013). Regional revenue (InRevenue) has a strong relationship to total expenditure and investment expenditure, and discretionary budget categories. The analysis result shows that if there is a change in revenue by 1 percent, then in such expenditures will change by 0.58 per cent and 0.48 per cent (both at 1 per cent significant level) respectively. The discretionary budget category shows that if there is an increase in revenue per capita by 1 per cent then in such expenditures are expected to increase by 0.39 per cent, (at 5 per cent significant level). This finding is also consistent with previous studies which suggest that discretionary spending has positive and significant relationship to discretionary funds (Sjahrir et al., 2013; Setiawan and Purnomowati, 2017). This evidence also reflects that the regional budget spending is closely related to the amount of revenue received by regional government.

On the number of populations (InPopsize), there is a negative and statistically significant effect on investment expenditure. The result suggests that if there is an increase in population number by 1 percent, it would expect that municipalities' investment expenditure decrease by 0.1 percent (at $5 \%$ significant level). This result seems contrary with previous studies which show the number of populations have positive and significant effect on budget spending, particularly in discretionary spending (Sjahrir, et al., 2013; Arifin and Purnomowati, 2017).

Interestingly, findings also related to Literacyrate show it has negative and significant relationship on investment, discretionary funds, and grant expenditure. It means, if there is an increase by 1 percent literacy rate in such regions, then it would expect that investment expenditure decrease by $0.004 \%$ (at $5 \%$ significant level) and by $0.003 \%$ (at $10 \%$ significant level). This result accordance with the previous studies that government tend to allocate carefully in such targeted expenditure when the level of ability of citizens to monitor the government policy sufficient (Sjahrir, et al., 2013).

The table above also shows that In District size result suggest a positive and significant connection on the total expenditure and grant expenditure, while it has a negative and significant effect on social expenditure. It means, an increase by 1 percent district areas will raise total spending about 0.01 per cent (at 10 per cent significance level). Similarly, the size of also become one of the considerations for municipalities government to spend budget in discretionary funds, particularly to distribute social expenditures among citizens. According to statistics result, an increase by 1 per cent of district size, then will decrease social assistance spending about 0.25 per cent (at 10 per cent significance level). This finding shows that the wider of regions areas might affects government to 
spend less in social assistance expenditure. Finally, regarding City shows that in Kota municipalities ten to decrease by 0.71 per cent and 2.89 per cent in discretionary funds and financial assistance expenditure respectively than in Kabupaten municipalities.

\section{Conclusion}

This study aims to empirically prove whether there is a difference in fiscal spending behaviour between regions that have eligible incumbents rerunning in the 2015 election and regions that have lame duck incumbents. The empirical model is applied to cross-sectional data and estimated using OLS method. This research uses public spending data of districts and cities in Indonesia which held simultaneous head local elections in 2015 over the period 2013-2015. The unit of observation is 237 municipalities in Indonesia.

According to the result, in general there is no difference spending behavior between regions that have re-runner incumbents and regions that have second-period incumbents in most of the observed spending categories during the election year (except in the grant subcomponent). However, the higher grant expenditure in a year before the election time, then the lower grant expenditure during election year in those regions.

The results in general show that the effect of the re-running eligibility on spending is not statistically significant. This seems to correlate with the fact that among regions with lame duck incumbents, more than half have vice head who were running in 2015 election. There might be an incentive for them to use spending to affect their re-electability similar to the condition in regions with rerunning head. However, there is a difference in the grant expenditure between regions that have re-running head and regions that have lame ducks. It is likely that re-runner incumbents prefer to choose this kind of subcomponent spending that can be utilized for the sake of their group or their vested interest.

Grants expenditure become popular among re-running incumbents compared to other type of expenditures, because they can raise the spending during the election year, and distribute the donation in relatively flexible, potentially have large benefit, and bring direct effect on voter's welfare. They can donate it to religious and/or social institutions, civil group activities, and even sport association to improve their good image upon electorates. In contrast, other type of expenditures, such as investment expenditure in general would needs more time to gain visible results upon voters, while social assistance expenditure usually more focus on individual or families rather than institutions.

Therefore, the revision of the Minister of Home Affairs Regulation Number 39 of 2012 which gives stricter rules to allocation of grant, however, will still not enough to control an opportunistic behavior in expenditure during the 2015 regional head general election. The restrictions regulation on grant 
expenditure and social assistance expenditure based on the regional government regional finance ability (fiscal space) is urgently needed. This prohibition also should be stated in the government policies to improve the existing regulation on donation and grants distribution.

\section{References}

Akhmedov, A., \& Zhuravskaya, E. (2004). 'Opportunistic political cycles: Test in a young democracy setting', quarterly journal of economics. The Quarterly Journal of Economics, 119(4), 1301-1338. doi:http://dx.doi.org/10.1162/0033553042476206

Alesina, A. (1987). Macroeconomic policy in a two-party system as a repeated game. Quarterly Journal of Economics, 102(3), 651-678.

Alesina, A., \& Paradisi, M. (2017). Political budget cycles: Evidence from italian cities. Econ Polit, 29, 157-177. doi:https://doi.org/10.1111/ecpo.12091

Alt, J. E., \& Lassen, D. D. (2006). Transparency, political polarization, and political budget cycles in OECD countries. American Journal of Political Science, 50(3), 530-550.

Arham, M. (2015)). Simultaneous regional elections for a better democracy. Retrieved from http://www.globalindonesianvoices.com/23701/simultaneous-regionalelections-for-a-better-democracy/

Arifin, T., \& Purnomowati, N. H. (2017). Government expenditure, political cycle and rent-seeking. International Journal of Business and Society, 18(3), 461-468.

Arsil, S. (2015, 04/02/2015). Mendagri: 343 kepala daerah tersangkut kasus hukum (minister of home affairs: 343 heads of district cases of legal cases). www.kompas.com

Aspinall, E. (2014). Democratic deepening in indonesia: Challenges for the new administration. Strategic Review,

Balaguer-Coll, M. T., Brun-Martos, M. I., Forte, A., \& Tortosa-Ausina, E. (2015). Local governments' re-election and its determinants: New evidence based on a bayesian approach. European Journal of Political Economy, 39, 94-108. doi:http://dx.doi.org/10.1016/j.ejpoleco.2015.04.004

Baskaran, T., Brender, A., Blesse, S., \& Reingewertz, Y. (2016). Revenue decentralization, central oversight and the political budget cycle: Evidence from israel. European Journal of Political Economy, 42(1-2), 116.

Bee, C. A., \& Moulton, S. R. (2015). Political budget cycles in U.S. municipalities. Economics of Governance, 16(4), 379-403. doi:10.1007/s10101-015-0171Z

Benito, B., Albaladejo, F. J. B., \& Vicente, C. (September 2012). Political budget cycles in local governments. Lex Localis, 4(4), 341-361. 
Besley, T., \& Case, A. (08/1995). Does electoral accountability affect economic policy choices? evidence from gubernatorial term limits. The Quarterly Journal of Economics, 110(3), 769-798. doi:DOI: 10.2307/2946699

Brender, A., Drazen, A., \& National Bureau of Economic Research. (2004). Political budget cycles in new versus established democracies. Cambridge, Mass.: National Bureau of Economic Research. Retrieved from National Bureau of Economic Research http://papers.nber.org/papers/w10539

Brender, A., \& Drazen, A. (2005). Political budget cycles in new versus established democracies doi:https://doi.org/10.1016/j.jmoneco.2005.04.004

Brender, A., \& Drazen, A. (January 2013). Elections, leaders, and the composition of government spending. Journal of Public Economics, 97, 18-31. doi:https://doi.org/10.1016/j.jpubeco.2012.08.011

Burden, B. C. (2009). The dynamic effects of education on voter turnout. Electoral Studies, 28(4), 540-549.

C. Pass, B., \& Lowes, L. D. (2005). Collins dictionary of economics, 4th ed. S.v. "government expenditure.". Retrieved from http://financialdictionary.thefreedictionary.com/government+expenditure

Cheema, G. S., \& D.A., R. (2007). 'From government decentralization to decentralizing governance'. In Cheema, G.S. \& Rondinelli, D.A. (Ed.), Decentralising governance: Emerging concepts and practices (pp. 1-20). Washington: The Brookings Institution Press.

Choi, N. (2007). Elections, parties and elites in indonesia's local politics. South East Asia Research, 15(3), 325-354. doi:10.5367/000000007782717731

Chortareas, G., Logothetis, V., \& Papandreou, A. A. (2016). Political budget cycles and reelection prospects in greece's municipalities. European Journal of Political Economy, 43, 1-13.

Director Generale of Regional Autonomy, \& Ministry of Home Affairs. (2015). Ministry of home affairs letters no. 120/4474/OTDA on confirmation of the last term of office of the head of the region in 2015.

Directorate General Fiscal Balance, MoF. (2017). Sistem informasi keuangan daerah 2011-2017. Retrieved from

http://www.djpk.depkeu.go.id/?page id=316

Directorate General of Regional Autonomy, MoHA. (2014). The formation of autonomous regions until 2014. accessed on 22th july 2017. Retrieved from

http://otda.kemendagri.go.id/CMS/Images/SubMenu/totalDOB.pdf

Drazen, A., \& Eslava, M. (2010). Electoral manipulation via voter-friendly spending: Theory and evidence. Journal of Development Economics, 92(1), 39-52. doi:https://doi.org/10.1016/j.jdeveco.2009.01.001

Drazen, A. (2008). Political budget cycles. In S. N. Durlauf, \& L. E. Blume (Eds.), The new palgrave dictionary of economics (Second Edition ed., ) Palgrave MacMillan. 
Dubois, E. (2016). Political Business Cycles 40 years after Nordhaus. Public Choice, 166(1), 235-259. doi:10.1007/s11127-016-0313-z

Efthyvoulou, G. (2012). Political budget cycles in the european union and the impact of political pressures. Public Choice, 153(3), 295-327. doi:10.1007/s11127-011-9795-x

Ferraz, C., \& Finan, F. (2011). Electoral accountability and corruption: Evidence from the audits of local governments. The American Economic Review, 101(14), 1273-1311. doi:doi:http://remote-lib.ui.ac.id:2090/10.1257/aer.101.4.1274

Galli, E., \& Rossi, S. P. S. (2002). Political Budget Cycles: The case of the Western German. Public Choice, 110(3), 283-303. doi:10.1023/A:1013089504557

Gujarati, D. N. (2003). Basic econometrics (4th ed.). Boston: McGraw Hil.

Henderson, J. V., \& Kuncoro, A. (2011). Corruption and local democratization in indonesia: The role of islamic parties. Journal of Development Economics, 94(2), 19 October 207-164-180. doi:https://doi.org/10.1016/j.jdeveco.2010.01.007

International Foundation for Electoral System. (n.d.). Indonesia's 2015 regional elections. Retrieved from ww.ifes.org/news/indonesias-2015-regionalelections

Johnson, J. M., \& Crain, W. M. (April 2004). Effects of term limits on fiscal performance: Evidence from democratic nations. Public Choice, 119(1/2), 73-90. doi:https://remote-lib.ui.ac.id:2094/stable/30025814

King, Y. D. (2003). Half-hearted reform: Electoral institutions and the struggle for democracy in indonesia. Wesport: Praeger Publishing.

Kis-Katos, K., \& Sjahrir, B. S. (2014). The impact of fiscal and political decentralization on local public investments in indonesia. IZA Duscussion Paper Series, IZA DP No. 7884, 12 July 2017.

Klein, F. a. (2010). Reelection incentives and political budget cycle: Evidence from brazil. Revista De Administracao Publica, , 283-337.

Klein, F. A., \& Sakurai, S. N. (2015). Term limits and political budget cycles at the local level: Evidence from a young democracy doi:https://doi.org/10.1016/j.ejpoleco.2014.10.008

List, J. A., \& Strum, D. M. (November 2006). How elections matter: Theory and evidence from environmental policy. The Quarterly Journal of Economics, 121(4), 1249-1281. doi:10.1162/qjec.121.4.1249

Lopes da Fonseca, M. (29 February 2016). Candid lame ducks. CESifo Working Paper Series, 5773

Ministry of Finance, Republic Indonesia. (2015). Informasi APBN 2016 (central budget of 2016 information).

Regulation of the minister of home affairs of the republic of indonesia no. $39 / 2012$ about amendment to regulation of the minister of home Affairs/2011 on grants, social aid guidlines funded by APBD, (2012). 
Muttaqin, T., van Duijn, M., Heyse, L., \& Wittek, R. (2016). The impact of decentralization on educational attainment in indonesia. In R. L. Holzhacker, R. Wittek \& J. Woltjer (Eds.), Decentralization and governance in indonesia (pp. 79-103). Cham: Springer International Publishing. doi:10.1007/978-3-319-22434-3_4 Retrieved from https://doi.org/10.1007/978-3-319-22434-3_4

Nachrowi, D. N., \& Usman, H. (2006). Pendekatan populer dan praktis ekonometrika untuk analisis ekonomi dan keuangan (popular and practical approach of econometrics for economic and finance analysis). Jakarta: Lembaga Penerbit Fakultas Ekonomi Universitas Indonesia.

Nasution, A. (2016). Government decentralization program in indonesia. $A D B /$ Working Paper, 601

Nogare, C. D., \& Galizzi, M. M. (August 2011). The political economy of cultural spending: Evidence from italian cities. Journal of Cultural Economics, 35(3), 203-231. doi:http://www.jstor.org/stable/23883725

Nogare, C. D., \& Kauder, B. (2017). Term limits for mayors and intergovernmental grants: Evidence from italian cities. Regional Science and Urban Economics, 64, 1-11.

doi:https://doi.org/10.1016/j.regsciurbeco.2017.01.004

Nogare, C. D., \& Ricciuti, R. (2011). Do term limits affect fiscal policy choices? European Journal of Political Economy, 27(4), 681-692. doi:https://doi.org/10.1016/j.ejpoleco.2011.06.006

Nordhaus, W. D. (1975). The political business cycle. Review of Economic Studies, 2, 169-190.

Ostwald K, Tajima Y, Samphantharak K. (2016). Indonesia's decentralization experiment: Motivations, successes, and unintended consequences. . Journal of Southeast Asian Economies, 33(2), 139-56.

Padovano, F., \& Petrarca, I. (June 2014). Are the responsibility and yardstick competition hypotheses mutually consistent? European Journal of Political Economy, 34, 459-477. doi:https://doi.org/10.1016/j.ejpoleco.2013.09.006

Peltzman, S. (1992). Voters as fiscal conservatives. The Quarterly Journal of Economics, 107(2), 327-361. doi:https://doi.org/ 10.2307/2118475

Persson, T., \& Tabellini, G. (2002). Political economics and public finance. In A. J. Auerbach, \& M. Feldstein (Eds.), Handbook of public economics (pp. 1549-1659) Elsevier. Retrieved from http://EconPapers.repec.org/RePEc:eee:pubchp:3-24

The law no. 33/2014 regarding regional election, (2014).

The law no. 8 of 2015 on amendment to law no. 1 of 2015 on stipulation of government regulation no. 1 of 2014 on the election of the governor, regent, and mayor be liable, (2015).

Ritonga, I. T., \& Alam, M. I. (2010). Apakah incumbent memanfaatkan anggaran pendapatan belanja daerah (APBD) untuk mencalonkan kembali dalam 
pemilihan umum kepala daerah (PEMILUKADA). Simposium Nasional Akutansi XIII, , 27 July 2017.

Rogoff, K., \& Sibert, A. (Jan., 1988). Elections and macroeconomic policy cycles. The Review of Economic Studies, 55(1), 1-16.

Sadikin, U. H. (April 2016). Menyerentakan pemilu, memusatkan anggaran pilkada. Jurnal Pemilu Dan Demokrasi, 8

Sakurai, S. N., \& Menezes-Filho, N. (2011). Opportunistic and partisan election cycles in brazil: A new evidence at the municipal level. Public Choice, 148(1), 233-247. doi:10.1007/s11127-010-9654-1

Setiawan, B. (2006, 07/01/2016). Petahana tetap kuat di pilkada 2015 (the incumbents have won in the regional election in 2015).

Setiawan, D., \& Rizkiah, F. (2017). International Journal of Business and Society, 18(3), 533-546.

Shi, M., \& Svensson, J. (2006). Political budget cycles: Do they differ across countries and why? Journal of Public Economics, 90(8-9), 1367-1389.

Sjahrir, B. S., Kis-Katos, K., \& Schulze, G. G. (2013). Political budget cycles in indonesia at the district level

doi:http://dx.doi.org/10.1016/j.econlet.2013.05.007

Smart, M., \& Sturm, D. M. (2013). Term limits and electoral accountability. Journal of Public Economics, 107, 93-103.

doi:https://doi.org/10.1016/j.jpubeco.2013.08.011

Smoke, P. (2007). 'Fiscal decentralisation and intergovernmental fiscal relations: Navigating a viable path to reform'. In Cheema, G.S. \& Rondinelli, D.A. (Ed.), Decentralising governance: Emerging concepts and practices (pp. 141-142). Washington: The Brookings Institution Press.

Statistics Indonesia. (2017). Financial statistics of Regency/Municipality government 2015-2016 book 1 and 2. ( No. 06310.1703). Jakarta: BPS.

Streb, J. M., Lema, D., \& Torrens, G. (2009). Checks and balances on political budget cycles: Cross country evidence. Kyklos, 62(3), 426-447. doi:10.1111/j.1467-6435.2009.00444.x

Surbakti, R. (January-March 2014). Understanding the flaws in indonesia's electoral democracy. Strategic Review,

The supreme constitutional court stipulation number 100/PUU-XIII/2015, (2015).

Veiga, L. G., \& Veiga, F. (2016). Term limits at the local government level. NIPE Working Papers, 07, 28 June 2018.

Veiga, L. G., \& Veiga, F. J. (2007). Does opportunism pay off? Economics Letters, 96(2), 177-182.

Vergne, C. (2009). Democracy, elections and allocation of public expenditures in developing countries doi:https://doi.org/10.1016/j.ejpoleco.2008.09.003

Vicente, C., Benito, B., \& Bastida, F. (2013). Transparency and political budget cycles at municipal level. Swiss Political Science Review, 19(2), 139-156.

Winoto, A. H., \& Falikhatun. (Juni 2015). Indikasi penyalahgunaan discretionary fund dalam anggaran pendapatan dan belanja daerah menjelang pemilukada 2015. Jurnal Akuntansi Dan Keuangan Indonesia, 12(1), 75 - 91. 